\title{
KINERJA PENYULUH AGAMA NON PNS KEMENTERIAN AGAMA
}

\author{
Ali Hamzah \\ Institut Agama Islam Negeri (LAIN) Kerinci \\ email: alihamzah@iainkerinci.ac.id
}

\begin{abstract}
Abstract: In addition, Islamic religious instructors in carrying out their duties and functions are assisted by non-civil servants of Islamic religious instructors consisting of religious leaders who are very instrumental in fostering religious communities to improve the faith, piety and harmony of religious people, especially in Sungai Penub City. The formulation of the problem in this study is how the performance of the Non government employees Religious Extension Ministry of Religion (Study in Sungai Penub City). This research is a qualitative research with a type of field research. Data collection techniques used include observation, interviews and documentation studies. In this study the author did the processing in several ways as follows: 1) data reduction (data reduction); 2) selecting data; 3) data analysis; 4) data presentation (data display); and 5) draw conclusions. The results of this study include: 1) the standard of performance of Non government employees religious instructors in the office of the Ministry of Religion in Sungai Penuh prioritized by a Bachelor of Religion Higher Education diploma, domiciled in the city of Sungai Penuh and having a built village; 2) performance criteria consist of 6 types, namely: quality, quantity, timeliness, cost effectiveness, need for supervision and interpersonal impact; and 3) the motivation given by the Ministry of Religion of Non government employees in the office of the Ministry of Religion of Sungai Penub City consists of 2, namely: intrinsic motivation and extrinsic motivation.
\end{abstract}

Keywords: Performance, Religion Extension, Non government employees

\begin{abstract}
Abstrak: Di samping itu penyuluh agama Islam fungsional dalam melaksanakan tugas dan fungsinya dibantu oleh penyuluh agama Islam non PNS yang terdiri dari tokoh agama yang sangat berperan dalam membina umat beragama guna meningkatkan keimanan, ketakwaan dan kerukunan umat beragama khususnya di Kota Sungai Penuh. Rumusan masalah dalam penelitian ini yakni bagaimana Kinerja Penyuluh Agama Non PNS Kementerian Agama (Studi di Kota Sungai Penuh). Penelitian ini adalah penelitian kualitatif dengan jenis penelitian field research. Teknik pengumpulan data yang digunakan antara lain observasi, wawancara dan studi dokumentasi. Dalam penelitian ini penulis melakukan pengolahan dengan beberapa cara sebagai berikut: 1) reduksi data (data reduction); 2) menyeleksi data; 3) analisis data; 4) penyajian data (data display); dan 5) menarik kesimpulan. Hasil penelitian ini antara lain: 1) standar kinerja penyuluh agama non PNS di kantor Kementerian Agama kota Sungai Penuh diprioritaskan berijazah S1 Perguruan Tinggi Agama, berdomisili di kota Sungai Penuh dan memiliki desa binaan; 2) kriteria kinerja terdiri dari 6 macam yaitu: kualitas, kuantitas, ketepatan waktu, efektifitas biaya, kebutuhan untuk suvervise dan dampak interpersonal; dan 3) motivasi yang diberikan oleh Kementerian agama non PNS di kantor Kementerian Agama kota Sungai Penuh terdiri dari 2 yaitu: motivasi instrinsik dan motivasi ekstrinsik.
\end{abstract}

Kata Kunci: Kinerja, Penyuluh Agama, Non PNS 


\section{PENDAHULUAN}

Kinerja dianggap penting bagi organisasi, karena keberhasilan suatu organisasi dipengaruhi oleh kinerja itu sendiri. Istilah kinerja berasal dari kata Job Performance atau Actual Performance (Prestasi kerja atau prestasi sesungguhnya yang dicapai oleh seseorang). Pengertian kinerja (prestasi kerja) adalah hasil kerja secara kualitas dan kuantitas yang dicapai oleh seorang pegawai dalam melaksanakan tugasnya sesuai dengan tanggungjawab yang diberikan kepadanya. ${ }^{1}$

Prawirosentono mengemukakan bahwa kinerja adalah hasil kerja yang dapat dicapai seseorang atau sekelompok orang dalam suatu organisasi, sesuai dengan wewenang dan tangungjawab masing-masing, dalam rangka upaya mencapai tujuan organisasi bersangkutan secara legal, tidak melanggar hukum, dan sesuai dengan moral maupun etika. Sedangkan Cormick dan Tiffin mengemukakan kinerja adalah kuantitas, kualitas, dan waktu yang digunakan dalam menjalankan tugas. ${ }^{2}$ Menurut Stephen P. Robbin kinerja merupakan hasil evaluasi kerja yang telah dilakukan dibanding dengan kriteria yang telah ditetapkam bersama. Dipihak lain Ahuya menjelaskan bahwa kinerja adalah cara perseorangan atau kelompok dari suatu organisasi untuk menyelesaikan pekerjaan atau tugas. ${ }^{3}$ Adapun ayat yang membahas tentang kinerja yaitu surat At-Taubah ayat $105^{4}$. Dari ayat ini dapat disimpulkan bahwa dalam melaksanakan tugas karyawan yang telah ditetapkan, hendaknya dalam melakukan pekerjaan tanpa adanya unsur keterpaksaan, tapi karena pekerjaan yang diberikan kepadanya adalah tanggung jawabnya, karena semua perbuatan yang dilakukan akan dipertanggung jawabkan pada akhirat kelak dan juga berpengaruh terhadap pekerjaan yang dilakukan diatas dunia ini yang berkaitan dengan hasil kerja dan upah yang diterima dari pekerjaan tersebut.

\footnotetext{
1 Anwar Prabu Mangkunegara, Manajemen Sumber Daya Manusia Perusahaan, (Bandung: PT Remaja Rosdakarya, 2009), h.67

${ }^{2}$ Edy Sutrisno, Budaya Organisasi, (Jakarta: Kencana, 2011), h.172

${ }^{3}$ I Gusti Agung Rai, Audit kinerja pada Sektor Publik, (Jakarta: Salemba Empat, 2008) h.40-41

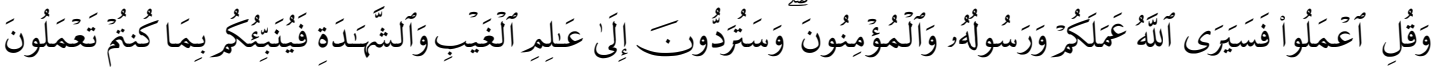

Dan Katakanlah: "Bekerjalah kamu, Maka Allah dan Rasul-Nya serta orang-orang mukmin akan melihat pekerjaanmu itu, dan kamu akan dikembalikan kepada (Allah) yang mengetahui akan yang ghaib dan yang nyata, lalu diberitakan-Nya kepada kamu apa yang telah kamu kerjakan.
} 
Secara teoritis, ada banyak faktor yang mempengaruhi kinerja seseorang. terdapat 3 faktor yang mempengaruhi yaitu: kemampuan dan minat seorang pekerja, kemampuan dan penerimaan atas penjelasan delegasi tugas, serta peran dan tingkat motivasi seorang pekerja. ${ }^{5}$

Kemudian pendapat lain dari McClelland menyebutkan faktor yang mempengaruhi kinerja adalah faktor kemampuan dan motivasi kerja. Menurut Steers mengemukakan umumnya orang percaya, bahwa prestasi kerja individu merupakan fungsi gabungan dari tiga faktor yaitu: 1) kemampuan, sikap dan minat seorang pekerja; 2) kejelasan dan penerimaan atas penjelasan peranan seorang pekerja; dan 3) tingkat motivasi kerja. ${ }^{6}$

Indikator kinerja mengacu pada penilaian kinerja secara tidak langsung, yaitu hal-hal yang bersifat hanya merupakan indikasi kinerja saja, sehingga bentuknya cenderung kualitatif atau tidak dapat dihitung (peningkatan, perputaran, tingkat, dan efektivitas). Sedangkan ukuran kinerja adalah kriteria yang mengacu pada penilaian kinerja secara langsung, sehingga lebih bersifat kuantitatif atau dapat dihitung (dalam bentuk persentase, perkalian, jumlah, unit dan rupiah). ${ }^{7}$

Yang dimaksud dengan penyuluh agama sebagaimana tercantum dalam Keputusan Menteri Agama RI Nomor 79 tahun 1985, adalah : "Pembimbing umat beragama dalam rangka pembinaan mental, moral dan ketaqwaan kepada Tuhan Yang Maha Esa, dan penyuluh agama Islam, yaitu pembimbing umat Islam dalam rangka pembinaan mental, moral dan ketakwaan kepada Tuhan Yang Maha Esa, Allah SWT, serta menjabarkan segala aspek pembangunan melalui pintu dan bahasa agama". 8

Di samping itu penyuluh agama Islam fungsional dalam melaksanakan tugas dan fungsinya dibantu oleh penyuluh agama Islam non PNS yang terdiri dari tokoh agama yang sangat berperan dalam membina umat beragama guna meningkatkan keimanan, ketakwaan dan kerukunan umat beragama khususnya di Kota Sungai Penuh. Penyuluh agama non PNS ditempatkan di KUA yang berada di setiap kecamatan Kota Sungai Penuh. Oleh karenanya, penulis meneliti penyuluh agama non PNS di setiap kecamatan yang ada di kota di Kota Sungai Penuh. Penyuluh agama non PNS berkewajiban menyampaikan penyuluhan kemasyarakat minimal sebanyak 12 kali dalam sebulan berarti 3 kali dalam seminggu, dalam menyampaikan penyuluhan-penyuluhan memiliki satu kelompok binaan. Penyuluh agama non PNS di Kota Sungai Penuh berjumlah 45 orang.

${ }^{5}$ Malayu S.P. Hasibuan, Manajemen Sumber Daya Manusia, (Jakarta: Bumi Aksara, 2009), h. 94

${ }^{6}$ Edy Sutrisno, Manajemen Sumber Daya Manusia, (Jakarta: Kencana, 2009), h.165 2014), h.32-33

7 Moeheriono, Perencanaan Aplikasi dan Pengembangan Indikator Kinerja Utama, Jakarta: Rajawali Press,

8 Departemen Agama RI, Panduan Tugas Penyuluh Agama Masyarakat, (Jakarta: Direktorat Jenderal Bimbingan Masyarakat Islam, Direktorat Penerangan Agama Islam, 2007), h.8-9 
Penetapan tenaga penyuluh agama non PNS merupakan usulan dari Kantor Urusan Agama Kecamatan yang disampaikan ke Kantor Kementerian Agama Kota Kota Sungai Penuh, kemudian Kantor Kementerian Agama mengusulkan Surat Keputusan (SK) Pengangkatan sesuai alokasi dana yang tersedia ke Kantor Wilayah Kementerian Agama Provinsi Jambi.

Lembaga Kementerian Agama merupakan Lembaga pemerintah yang mengurusi tentang urusan agama, salah satu bidang yang berada di dalam Kementerian Agama yakni Bimas Islam (Bimbingan Masyarakat Islam). Kasi Bimas Islam adalah Drs. H. Hasyari, yang salah satu programnya memberikan pengetahuan agama Islam di tengah masyarakat dengan lokasi Masjid, MDA, TPQ, TPSQ, Sebagai Da’i/Mubalig dan tenaga pengajar, membentuk kelompok yasinan, melaksanakan kegiatan BKMT, mengajar santri dan santriwati di Pondok Pesantren. Untuk menyukseskan program ini Bimas Islam dibantu oleh penyuluh agama fungsional.

Adapun aturan yang mengatur tentang Penyuluh Agama Non PNS adalah Keputusan Menteri Agama (KMA) No 79 Tahun 1985 tentang Penyuluh Agama Non PNS, Keputusan Menteri Agama (KMA) No 164 Tahun 1996 tentang honorarium bagi Penyuluh Agama, Keputusan Menteri Agama (KMA) No. 150 Tahun 2011 tentang Penetapan honorarium bagi Penyuluh Agama non PNS, Keputusan Menteri Agama (KMA) No. 148 Tahun 2014 tentang Penetapan honorarium bagi Penyuluh Agama non PNS, Keputusan Menteri Agama (KMA) No. 776 Tahun 2016 tentang Penetapan honorarium bagi Penyuluh Agama non PNS, dan Keputusan Direktur Jenderal Bimbingan Masyarakat Islam No. 298 Tahun 2017 tentang Pedoman Penyuluh Agama Islam non PNS.

Tugas pokok dan fungsi (Tupoksi) penyuluh agama non PNS yaitu: 1) melaksanakan tugas penyuluhan di tengah masyarakat dengan lokasi Masjid, MDA, TPQ, TPSQ, sebagai Da’i/Mubaligh dan tenaga pengajar; 2) melaksanakan tugas keagamaan dan perayaan hari keagamaan; 3) melaksanakan tugas keagamaan ditingkat Kecamatan dibawah koordinasi Kepala KUA dan di tingkat Kota dibawah koordinasi Kasi Bimas dibawah arahan Kepala Kankemenag; 4) menyiapkan data keagamaan yang ada di wilayah binaan Penyuluh Agama; 5) berperan aktif setiap kegiatan keagamaan yang ada di wilayah penyuluhan; 6) peduli, tanggap dan responsif terhadap peristiwa keagamaan yang ada di wilayah penyuluhan; 7) selalu siap bekerjasama dengan unsur terkait dalam melaksanakan tugas; 8) selalu siap dipanggil melaksanakan tugas apabila dibutuhkan; 9) memelihara martabat, harga diri dan moral di

\footnotetext{
${ }^{9}$ Iskandar, Penyuluh Agama Non PNS, Wawancara langsung, pada tanggal 10 Oktober 2017, jam 11.00.
} 
tengah masyarakat; dan 10) membentuk wadah penyuluhan agama tingkat Kecamatan dan Kota. ${ }^{10}$

Berdasarkan tugas pokok dan fungsi (Tupoksi) di atas penyuluh agama Islam non PNS berperan sangat penting di tengah masyarakat dan kedudukannya cukup besar di tengah masyarakat. Penyuluh agama Islam adalah para juru penerang penyampai pesan bagi masyarakat mengenai prinsip-prinsip dan etika nilai keberagamaan yang baik. Di samping itu penyuluh agama Islam merupakan ujung tombak dalam pelaksanaan tugas membimbing umat Islam dalam mencapai kehidupan yang bermutu dan sejahtera lahir bathin, sehingga terwujudnya kehidupan masyarakat yang memiliki pemahaman mengenai agamanya secara memadai yang ditunjukkan melalui pengamalannya yang penuh komitmen dan konsisten seraya disertai wawasan multikultural untuk mewujudkan tatanan kehidupan yang harmonis dan saling menghargai satu sama lain.

Adapun Alur Tugas dari Penyuluh Agama Non PNS yaitu: 1) laporan sesuai lokasi yang ada di SK; 2) membuat laporan mingguan yang diketahui oleh pengurus Masjid/MDA/Mushalla/Stempel; 3) laporan mingguan yang di sampaikan ke KUA; 4) membuat laporan bulanan minimal 8 kegiatan diketahui kepala KUA/Stempel; 5) laporan bulanan disampaikan ke Kemenag c.q Seksi Bimas paling Lambat tanggal 5 setiap bulan; dan 6) laporan bulanan dengan pengantar dari KUA

Berdasarkan observasi yang Penulis lakukan pada tanggal 9 Oktober 2017 dan wawancara dengan Drs. H. Hasyari menjelaskan bahwa Kinerja penyuluh agama Islam non PNS Kementerian Agama Kota Sungai Penuh belum maksimal, artinya belum menunjukan kuantitas kerja yang sesuai dengan target yang ditentukan dan kurang memiliki kualitas kerja yang baik, hal ini terlihat dari pengumpulan laporan yang tidak tepat waktu. ${ }^{11}$

Berdasarkan observasi dan wawancara yang penulis lakukan bahwa sebagian Penyuluh Agama Non PNS hanya mengharapkan Surat Keputusan (SK) untuk digunakan sebagai persyaratan menjadi PNS. Ada sebagian Penyuluh Agama Non PNS yang tidak bertanggung jawab sesuai dengan tugas pokok dan fungsinya. Salah satu faktor yang menyebabkan rendahnya kinerja Penyuluh Agama Non PNS Kota Sungai Penuh, di antaranya pemberian gaji yang minim dengan kisaran Rp.500.000 perbulan, itupun diterima 1 kali dalam 6 bulan. Penulis menemukan di lapangan ada sebagian penyuluh agama melakukan pelanggaran terhadap disiplin kerja seperti mengumpulkan laporan bulanan yang tidak tepat waktu yang menunjukkan tidak konsistennya penyuluh agama non PNS dengan disiplin kerja, untuk itu

${ }^{10}$ Pedoman kerja Tugas Pokok dan Fungsi penyuluh Agama Non PNS SeKota Sungai Penuh

${ }^{11}$ Hasyari, Kasi Bimas Islam, wawancara langsung, pada tanggal 9 Oktober 2017, jam 10.00. 
kinerja penyuluh agama non PNS perlu ditingkatkan agar menghasilkan kinerja yang maksimal.

Berdasarkan latar belakang masalah sebelumnya maka penulis memberikan rumusan masalah yaitu : Bagaimana Kinerja Penyuluh Agama Non PNS Kementerian Agama (Studi di Kota Sungai Penuh).

\section{METODE}

Penelitian ini adalah penelitian yang menggunakan metode penelitian kualitatif. Jenis penelitian yang dilakukan adalah penelitian lapangan (field research). Sumber data dalam penelitian ini diperoleh dari Kementerian Agama (Studi di Kota Sungai Penuh Kota Sungai Penuh), dalam hal ini adalah data yang diperoleh dari Penyuluh Agama Non PNS, Penyuluh Agama Fungsional dan Staf Bimas beserta Seksi Bimas Islam di Kementerian Agama Kota Sungai Penuh, kemudian data sekunder berupa buku-buku, buku kas, SK Penyuluh Agama Non PNS, arsip, serta buku panduan Kementerian Agama (Studi di Kota Sungai Penuh).Adapun teknik pengumpulan data yang digunakan antara lain observasi, wawancara dan studi dokumentasi. Dalam penelitian ini penulis melakukan pengolahan dengan beberapa cara sebagai berikut: 1) reduksi data (data reduction); 2) menyeleksi data; 3) analisis data; 4) penyajian data (data display); dan 5) menarik kesimpulan.

\section{HASIL PENELITIAN DAN PEMBAHASAN}

\section{Standar Kinerja Penyuluh Agama Non PNS}

Kinerja adalah hasil kerja yang dapat dicapai oleh seseorang atau sekelompok orang dalam suatu organisasi, sesuai dengan wewenang dan tanggung-jawab masing-masing, dalam rangka upaya mencapai tujuan organisasi bersangkutan secara legal, tidak melanggar hukum dan sesuai dengan moral maupun etika.

Bagian yang tak terpisahkan dari kinerja adalah prestasi kerja atau hasil kerja (output) baik kualitas maupun kuantitas yang dicapai sumber daya manusia perperiode waktu dalam melaksanakan tugas kerjanya sesuai dengan tanggungjawab yang diberikan kepadanya.

Kinerja pegawai adalah hasil kerja yang dicapai oleh seluruh pegawai dalam suatu organisasi sesuai dengan wewenang dan tanggungjawab dalam rangka upaya mencapai tujuan organisasi yang bersangkutan secara legal, tidak melanggar hukum dan sesuai dengan moral maupun etika. 
Untuk mencapai tujuan kinerja karyawan, dapat dinilai dari tiga hal meliputi: penilaian harus mempunyai hubungan dengan pekerjaan, adanya standar pelaksanaan kerja, dan praktis (mudah dipahami atau dimengerti karyawan atau penilai)".

"Standar kinerja adalah target, sasaran, tujuan upaya kerja karyawan dalam kurun waktu tertentu. Dalam melaksanakan pekerjaannya, karyawan harus mengarahkan semua tenaga, pikiran, ketrampilan, pengetahuan, dan waktu kerjanya untuk mencapai apa yang ditentukan oleh standar kinerja".

Kemudian standar kinerja dapat dilihat dari tiga bagian, yaitu standar input, standar proses dan standar hasil.

Berdasarkan hasil wawancara dapat penulis simpulkan bahwa standar kinerja penyuluh agama non PNS Kementerian Agama di Kota Sungai Penuh yaitu: diprioritaskan berijazah S1 perguruan tinggi agama, berdomisili di Sungai Penuh dan memiliki desa binaan. Kemudian dari segi proses, bahwa penyuluh agama non PNS harus melakukan penyuluhan ke desa binaan minimal 8 kali dalam sebulan dan wajib membuat hasil laporan yang diketahui oleh kepala KUA masing-masing. Selanjutnya dari segi standar hasil bahwa penyuluh agama harus merujuk kepada tujuan dan tugas pokok dan fungsi sebagai penyuluh agama non PNS yang telah ditetapkan.

\section{Kriteria Kinerja Penyuluh Agama Non PNS}

Kualitas (Mutu)

Seberapa jauh atau baik proses atau hasil menjalankan aktivitas mendekati kesempurnaan, ditinjau dari kesesuaian dengan cara ideal menjalankan suatu kegiatan atau memenuhi tujuan yang dikehendaki oleh suatu aktivitas.

Kualitas pekerjaan ini berhubungan dengan mutu yang dihasilkan oleh para pegawai dari suatu pekerjaan dalam organisasi, dimana kualitas pekerjaan ini mencerminkan tingkat kepuasan dalam penyelesaian pekerjaan dan kesesuaian pekerjaan yang diharapkan oleh organisasi. Selain itu kualitas juga bisa diartikan dengan melihat bagaimana pekerjaan dilakukan sesuai dengan yang diperintahkan sehingga pekerjaan yang dilakukan berdasarkan input yang ada akan mencapai target/sasaran kerja yang ditetapkan.

Kualitas adalah segala bentuk satuan ukuran yang terkait dengan mutu atau kualitas hasil kerja dan dinyatakan dalam ukuran angka atau yang dapat dipadankan dengan angka.

Berdasarkan wawancara yang penulis lakukan dengan kasi Bimas Islam target output pekerjaan dan hasil yang dapat direalisasikan oleh penyuluh maka dapat dilihat bahwa setiap penyuluh telah menyelesaikan tugas dan pekerjaan yang telah ditetapkan. Ini menunjukkan 
kuantitas dari beban pekerjaan yang diberikan terhadap masing-masing penyuluh mampu diselesaikan oleh masing-masing penyuluh. Sehingga tidak perlu mengurangi beban pekerjaan, bahkan dapat ditambah tugas penyuluh bila dianggap penting.

\section{Kuantitas (Jumlah)}

Kuantitas merupakan jumlah yang dihasilkan yang dinyatakan dalam nilai rupiah, jumlah unit, atau jumlah siklus kegiatan yang telah diselesaikan. Aspek kuantitas adalah aspek yang menggambarkan tingkat kesesuaian antara jumlah yang dihasilkan, diberikan, atau diselesaikan dalam suatu tugas pokok seorang pegawai non PNS dengan target yang telah disepakati dalam tugas pokok tersebut. Kuantitas pekerjaan dapat diperoleh dari hasil pengukuran kerja atau penetapan tujuan partisipatif.

Berdasarkan wawancara yang penulis lakukan dengan kasi Bimas Islam target output pekerjaan dan hasil yang dapat direalisasikan oleh penyuluh maka dapat dilihat bahwa setiap penyuluh telah menyelesaikan tugas dan pekerjaan yang telah ditetapkan. Ini menunjukkan bahwa untuk kuantitas dari beban pekerjaan yang diberikan terhadap masing-masing penyuluh tidak menjadi masalah dan mampu diselesaikan oleh masing-masing penyuluh. Sehingga tidak perlu mengurangi beban pekerjaan dan bahkan mungkin dapat diberikan tugas yang lebih.

\section{Ketetapan waktu}

Seberapa jauh atau baik aktivitas yang diselesaikan, atau hasil yang diproduksi, pada waktu yang awal yang dikehendaki dari sudut koordinasi dengan output yang lain maupun memaksimumkan waktu yang ada untuk kegiatan-kegiatan lain.

Ketepatan waktu ini berhubungan dengan waktu penyelesaian tugas (pekerjaan) sesuai dengan waktu yang diberikan. Setiap pekerjaan yang dilakukan oleh para pegawai memiliki standar waktu yang telah ditentukan. Penyuluh agama non PNS harus melaksanakan tugas sesuai dengan waktu yang telah ditentukan, dalam hal ini diantaranya: ketepatan waktu dalam menyelesaikan pekerjaan dan pekerjaan selesai pada saat dibutuhkan.

Berdasarkan wawancara yang dilakukan terhadap Kasi bimas melakukan penilaian terhadap kinerja penyuluh Agama non PNS dengan melihat laporan mingguan dan laporan bulanan. Dan dari sanalah Kasi bimas mengetahui Penyuluh yang bekerja dengan serius kemudian Kasi Bimas juga menilai dari bentuk-bentuk kegiatan yang dilakukan seperti: pelaksanaan MTQ, mengajar MIN, wirid pengajian, penyelenggaraan jenazah dan sebagainya. Ada penyuluh agama melakukan penyuluhan kurang dari 8 kali dalam sebulan dan tidak disiplin dalam mengumpulkan laporan. 


\section{Efektifitas biaya}

Seberapa jauh atau baik sumber daya organisasi (misalnya manusia, moneter, teknologi, bahan) dimaksimumkan dalam pengertian memperoleh keuntungan tertinggi atau pengurangan dalam kerugian dari masing-masing unit, atau contoh penggunaan sumber daya manusia.

Efektivitas biaya disini mengenai tingkatan dimana penggunaan sumber dana organisasi yang mana di dalamnya menyangkut penggunaan keuangan dimaksimalkan untuk mendapatkan hasil yang tertinggi atau pengurangan kerugian dari tiap unit. Di dalam melaksanakan tugasnya para penyuluh diharapkan untuk dapat memberdayakan/menggunakan segala sumber daya keuangan yang ada digdalam organisasi yang bersangkutan guna membantu penyelesaian tugas pekerjaan baik dari segi waktu maupun hasil kerja.

Rata-rata penyuluh dapat menggunakan biaya yang sesuai target yang telah ditetapkan. Ini berarti bahwa apa yang diharapkan bisa terealisasi atau bahkan lebih menghemat anggaran. Dalam melaksanakan kegiatan biasanya penyuluh melakukannya dengan menggalang sumbangan suka rela berhubung karena dana sangat minim.

\section{Kebutuban untuk supervisi}

Seberapa jauh atau baik seorang karyawan dapat melaksanakan fungsi kerja tanpa harus meminta bantuan pengawasan atau memerlukan intervensi pengawasan untuk mencegah hasil yang merugikan.

Kebutuhan untuk supervisi sangat diperlukan, karena dengan adanya pengawasan yang dilakukan secara berskala, tujuannya untuk memonitor kinerja penyuluh agama non PNS di kantor Kemenag Kota Sungai Penuh. Umpamanya ada penyuluh yang kurang melaksanakan tugas dan berpenampilan kurang sopan, maka akan dilakukan pembinaan cepat dengan cara dipanggil oleh penyuluh fungsional, jika Penyuluh Fungsional kewalahan, maka Kasi Bimas yang yang memberikan nasehat. Hal ini dilakukan secara bertahap dan berjenjang.

\section{Dampak interpersonal}

Seberapa jauh atau baik karyawan meningkatkan harga diri, itikad baik (goodwill) dan kerjasama antara karyawan dan bawahan.

Dampak interpersonal sebagai pelaksanaan tugas pokok dan fungsi penyuluh Agama Non PNS Kementerian Agama (Studi di Kecamatan Sungai Penuh Selatan Kota Sungai Penuh) sebagai motivator harus mampu menyesuaikan dengan keadaan. 
Jadi, dari observasi dan hasil wawancara yang penulis lakukan dapat disimpulkan bahwa kriteria kinerja terdiri dari 6 macam yaitu: kualitas, kuantitas, ketepatan waktu, efektifitas biaya, kebutuhan untuk suvervise dan dampak interpersonal. Pertama kinerja dilihat dari kualitasnya yaitu:sudah cukup baik. Penyuluh agama non PNS memiliki kemampuan yang berbeda-beda, rata-rata penyuluh lulusan sarjana pendidikan agama Islam. Adapun prestasi penyuluh agama non PNS yaitu sebagai berikut: terbina kegiatan MTQ, majelis taklim dan kegiatan keagamaan lainnya. Kedua nilai kuantitas kisaran 70-85.Ketiga ketepatan waktu dilihat dari pengumpulan laporan kegiatan bulanan yang tidak disiplin isi laporan yang belum sistematis dan rapi. Keempat efektifitas biaya dalam melaksanakan kegiatan biasanya penyuluh melakukannya dengan suka rela karena berhubungan dana yang minim. Kelima kebutuhan untuk suvervise, disini suvervisor sangat diperlukan untuk menghasilkan kinerja yang maksimal, pengawasan ini dilakukan dengan cara berskala. Selanjutnya keenam dampak interpersonal, Penyuluh agama non PNS menjadi contoh ditengah Masyarakat, harus mampu menyesuaikan kondisi dengan keadaan.

\section{Pemberian Motivasi yang dilakukan oleh Kementerian Agama terhadap Penyuluh Agama Non PNS}

Motivasi merupakan satu penggerak dari dalam hati seseorang untuk melakukan atau mencapai sesuatu tujuan. Motivasi juga bisa dikatakan sebagai rencana atau keinginan untuk menuju kesuksesan dan menghindari kegagalan kehidupan. Motivasi diperlukan untuk menciptakan kegairahan seseorang dalam bekerja. Motivasi adalah pemberian daya penggerak yang menciptakan kegairahan kerja seseorang, agar mereka mau bekerja sama, bekerja efektif dan terintegrasi dengan segala daya upaya untuk mencapai kepuasaan. Motivasi sebagai suatu kerelaan berusaha seoptimal mungkin dalam pencapaian tujuan organisasi yang dipengaruhi oleh kemampuan usaha memuaskan beberapa kebutuhan individu. Adapun motivasi dapat dikategorikan kepada dua macam, yaitu motivasi instrinsik dan motivasi ekstrinsik.

Adapun yang memotivasi Penyuluh Agama Non PNS di kankemenag Kota Sungai Penuh untuk bekerja, secara umum untuk mendapatkan honor atau gaji yang diterima sebanyak Rp. 500.000 perbulan. Pernyataan ini diperkuat oleh hasil wawancara penulis dengan Kasi Bimas Islam Kementerian Agama Kota Sungai Penuh.

Kemudian usaha yang dilakukan oleh Kementerian Agama Kota Sungai Penuh terhadap kelancaran kinerja dapat berjalan dengan lancar yaitu: dengan memberikan: bimbingan, pelatihan dan motivasi. Adapun bimbingan yang dilakukan seperti: diarahkan oleh penyuluh fungsional kepada Penyuluh Agama Non PNS yang kurang paham dengan masalah 
pekerjaan. Selanjutnya memberikan pelatihan kepada Penyuluh agama non PNS dengan bertujuan agar Penyuluh Agama Non PNS mampu bekerja lebih efisien dan efektif.

Penulis simpulkan dari wawancara yang dilakukan bahwa motivasi yang diberikan oleh Kementerian agama terhadap penyuluh agama non PNS di Kecamatan Sungai Penuh Selatan terdiri dari 2 yaitu: Motivasi Instrinsik dan motivasi ekstrinsik. Pertama motivasi instrinsik ialah selalu memberikan binaan rutin 2 kali dalam setahun terhadap Penyuluh Agama Non PNS. Sedangkan motivasi ekstrinsik kementerian Agama Kota Sungai Penuh memberikan insentif perbulan yang jumlahnya Rp.500.000 perbulan dan juga diberikan pakaian seragam. Selanjutnya diberikan juga reward (penghargaan) seperti dinobatkan sebagai penyuluh teladan jika kinerjanya bagus.

\section{PENUTUP}

Berdasarkan pemaparan di atas, penulis dapat membuat kesimpulan sebagai berikut: 1) standar kinerja penyuluh agama non PNS di kantor Kementerian Agama kota Sungai Penuh diprioritaskan berijazah S1 Perguruan Tinggi Agama, berdomisili di kota Sungai Penuh dan memiliki desa binaan. Konsekuensi sebagai penyuluh agama non PNS wajib melakukan penyuluhan ke desa binaan minimal 8 kali dalam sebulan dan membuat laporan yang diketahui oleh kasi Bimas Islam yang merujuk kepada tugas pokok dan fungsi sebagai penyuluh agama non PNS yang telah ditetapkan. 2) Penyuluh agama non PNS di kantor Kementerian Agama kota Sungai Penuh umumnya alumni Perguruan Tinggi Agama Islam. Adapun prestasi penyuluh agama honorer yaitu sebagai berikut: terbina kegiatan MTQ, majelis taklim dan kegiatan keagamaan lainnya. Kedua nilai kuantitas kisaran 70-85. Ketiga ketepatan waktu dilihat dari pengumpulan laporan kegiatan bulanan yang tidak disiplin dari segi maupun isi laporan yang belum sistematis dan rapi. Keempat efektifitas biaya dalam melaksanakan kegiatan biasanya penyuluh melakukannya dengan suka rela karena berhubungan dana yang minim. Kelima kebutuhan untuk supervise, disini suvervisor sangat diperlukan untuk menghasilkan kinerja yang maksimal, pengawasan ini dilakukan dengan cara berskala. Selanjutnya keenam dampak interpersonal, Penyuluh agama non PNS menjadi contoh di tengah masyarakat, harus mampu menyesuaikan kondisi dengan keadaan. 3) Motivasi yang diberikan oleh Kementerian agama non PNS di kantor Kementerian Agama kota Sungai Penuh terdiri dari 2 yaitu: Motivasi Instrinsik dan motivasi ekstrinsik. Pertama motivasi instrinsik ialah selalu memberikan binaan rutin 2 kali dalam setahun terhadap Penyuluh Agama Honorer. Sedangkan motivasi ekstrinsik Penyuluh Agama non PNS di kantor Kementerian 
Agama kota Sungai Penuh memberikan insentif perbulan yang jumlahnya bervariasi dengan total jumlah lebih kurang Rp.500.000 perbulan dan juga diberikan pakaian seragam. Selanjutnya diberikan juga reward (penghargaan) seperti dinobatkan sebagai penyuluh teladan jika kinerjanya bagus.

\section{REFERENSI}

Anwar Prabu Mangkunegara, Manajemen Sumber Daya Manusia Perusahaan, (Bandung: PT Remaja Rosdakarya, 2009)

Suharsimi Arikunto, Prosedur Penelitian suatu Pendekatan Praktik, (Jakarta: Rineka Cipta, 2005)

Depertemen Agama RI, Panduan Tugas Penyuluh Agama Masyarakat, (Jakarta: Direktorat Jenderal Bimbingan Masyarakat Islam, Direktorat Penerangan Agama Islam, 2007)

Edy Sutrisno, Manajemen Sumber Daya Manusia, (Jakarta: Kencana, 2009)

------, Budaya Organisasi, (Jakarta: Kencana, 2011)

Emzir, Metodologi Penelitian Kualitatif Analisis Data, (Jakarta: Rajawali Pers, 2012)

Etta Mamang Sangadji, et al. Metodologi Penelitian, (Yogyakarta:CV Andi Offset, 2010)

Juliansyah Noor, Metodologi Penelitian Kualitatif, (Jakarta: Kencana, 2011)

Lexy J. Moleong, Metodologi Penelitian Kualitatif, (Bandung: PT RemajaRosdaKarya, 2010)

Malayu S.P. Hasibuan, Manajemen Sumber Daya Manusia, (Jakarta: Bumi Aksara, 2009)

Moeheriono, Perencanaan Aplikasi dan Pengembangan Indikator Kinerja Utama, (Jakarta: Rajawali Press, 2014)

Pedoman kerja Tugas Pokok dan Fungsi penyuluh Agama Non PNS SeKota Sungai Penuh

Rosady Ruslan, Metode Penelitian Public Relations dan Komunikasi, (Jakarta:PT Raja Grafindo Persada, 2004)

Sugiyono, Metode Penelitian Kualitatif Kuantitatif dan R\&D, (Bandung: Alfabeta, 2012)

Suharsimi Arikunto, Manajemen Penelitian, (Jakarta: PT Rineka Cipta, 2005)

Sutopo dan Arief, Terampil Mengola Data Kualitatif.(Jakarta: Kencana, 2010) 